\title{
Disiplinlerarası Yaklaşıma İlişkin Ortaöğretim Öğretmenlerinin Görüşleri ve Ders Uygulamaları ${ }^{1}$
}

\begin{tabular}{lccc}
\hline MAKALE TÜRÜ & Başvuru Tarihi & Kabul Tarihi & Erken Görünüm Tarihi \\
Araştırma Makalesi & 23.7 .2018 & 8.4 .2019 & 9.4 .2019 \\
\hline
\end{tabular}

\section{Belgin Özaydınlı Tanrıverdi (iD) ${ }^{2}$ ve Cihan Kılıç}

Kocaeli Üniversitesi

\section{Öz}

$\mathrm{Bu}$ araştırmanın amacı, disiplinlerarası öğretim yaklaşımı bağlamında, matematik dersi temelinde, ortaöğretim matematik, fizik, kimya ve biyoloji öğretmenlerinin görüşlerini ve dersteki uygulamalarını ortaya koymaktır. Bu araştırmada nitel araştırma desenlerinden durum çalışması, verilerin çözümlenmesinde ise içerik analizi kullanılmıştır. Araştırmaya Marmara Bölgesindeki çeşitli Anadolu Liselerinde görev yapan 70 öğretmen katılmıştır. Veri toplama aracı araştırmacılar tarafından geliştirilmiş açık uçlu sorulardan oluşmaktadır. Araştırmanın sonucunda öğretmenlerin disiplinlerarası öğretim hakkında kavramsal düzeyde bilgi sahibi oldukları ve disiplinlerarası öğretimi ögrencilerin akademik başarısını arttırmada ve olumlu tutum geliştirmede etkili buldukları ortaya çıkmıştır. Öğretmenler matematik konularından en çok oran-orantı konusunun tüm fen dersleriyle, türev konusunun fizik, logaritma konusunun kimya ve olasılık konusunun da biyoloji dersleriyle ilișkili olduğunu düşünmektedirler. Disiplinlerarası öğretime ilişkin bu olumlu görüşlerine karşın öğretmenlerin büyük bir bölümünün sınıf içinde zaman azlığı ve programın yoğun olması gibi nedenlerle disiplinlerarası uygulamalara yer veremedikleri görülmektedir. Uygulama yaptıklarını belirten öğretmenlerin de büyük bir bölümünün, disiplinlerarası yaklaşıma dönük olumlu tutuma sahip olmalarına karşın, disiplinlerarası bir ders anlatımını planlayamadıkları görülmektedir.

Anahtar sözcükler: Disiplinlerarası öğretim, ilişkilendirme becerisi, ortaöğretim matematik, fizik, kimya ve biyoloji ögretmenleri.

${ }^{1} \mathrm{Bu}$ araştırma 25-28 Ekim 2017 tarihleri arasında Muğla'da gerçekleştirilmiş olan Uluslararası Eğitim Programları ve Öğretim (ICCI-EPOK- 2017) kongresinde bildiri olarak sunulmuş ve öneriler doğrultusunda geliştirilmiștir.

${ }^{2}$ Sorumlu Yazar: Doç. Dr, Eğitim Fakültesi, Eğitim Bilimleri Bölümü, Eğitim Programları ve Öğretim Anabilim Dalı, E-posta: belgintnvrd@ gmail.com, https://orcid.org/0000-0002-2134-8087

${ }^{3}$ Yüksek Lisans Öğrencisi, Sosyal Bilimler Enstitüsü, Eğitim Programları ve Öğretim Ana Bilim Dalı, Eposta: cihankilic88@gmail.com, https://orcid.org/0000-0003-4618-8857 
1940’lı yıllarda gelişmeye başlayan Esasicilik felsefesinin ürünü olan disipliner öğretim kavramı, belirli bir konu alanı (Matematik, Tarih gibi) çerçevesinde yapılan öğretim olarak belirtilmektedir. Bu yaklaşımda dersler ayrı ayrı işlenmekte; öğrencinin disiplinlerarası aktarma işini kendiliğinden yaptığı varsayılarak bilginin sentezlenmesiyle ilgili herhangi bir etkinlik yapılmamaktadır (Yıldırım, 1996). İlerlemeci eğitim anlayışıyla birlikte gelişen disiplinlerarası öğretim ise temel olarak geleneksel konu alanlarının belirli kavramların anlamlı biçimde bir araya getirilerek sunulması olarak açıklanmaktadır (Yıldırım, 1996).

Farklı disiplinleri birbirleri ile ilişkilendirerek yapılan çalışmalara bakıldığında aslında bu kavramın çok daha eskilere dayandığı görülmektedir. Sözgelişi; fizikçi, matematikçi, astronom, filozof ve ilahiyatçı olan Isaac Newton'un yüksek matematiğin temellerini atması; Albert Einstein'ın kuramsal fizikçi olup kimya ve matematiğe katkıda bulunan çalışmalar yapması; Galileo Galilei'nin fizikçi, matematikçi, astronom ve mühendis olup modern bilimin temellerini atması gibi gelişmeler disiplinlerarası çalışmaların birer ürünüdür.

Bir dersin farklı derslerle ilişkilendirilmesi ise eğitim programlarında disiplinlerarası öğretim ya da disiplinlerarası yaklaşım adıyla yerini almıştır. Jacobs (1989) disiplinlerarası yaklaşımı bir kavram, konu ya da deneyimin işlenmesi için farklı disiplinlerin yöntem bilgisini işe koşan program anlayışı olarak tanımlarken Yalçın (2013) iki veya daha fazla disiplinin ya da inceleme alanının birleștirilmesi ya da kapsanması biçiminde açıklamaktadır. Disiplinlerarası yaklaşımda temel anlayış bütünleştirmenin ya da ilişkilendirilmenin öğretmen tarafından yapılmasıdır. Bu açıdan bakıldığında ilişkilendirmede bir rastlantısallık ya da rastgelelik değil, bilinçlilik söz konusudur.

Bu tanımlardan yola çıkarak disiplinlerarası öğretim kavramı, merkeze bir tema alınarak bu temanın yeri geldiği zaman başka derslerle ilişkilendirilmesi olarak açıklanabilir. Bu yaklaşımda belirli bir kavramın, sorunun veya konunun temele alınması, farklı açılardan aydınlatabilecek bilgi ve becerilerin bunlarla ilişkili disiplinlerden alınarak bütünleştirilmesi söz konusudur (Aydın ve Balım, 2005; Yıldırım, 1996). Yıldırım'a (1996) göre dersin öğretmeni asıl anlatılması gereken temadan sapmadan, diğer dersin konusunun hepsini değil, sadece kendi konusuyla ilişkili olan kısmını anlatarak dersini şekillendirir. Yıldırım (1996) böylesi bir dersteki temel amacın, öğrencinin ayrı ayrı bilgileri bir araya getirerek ilişkilendirmesi, diğer bir deyişle bütünlük oluşturması ve konuyu değişik açılardan yorumlaması olarak belirtmektedir. $\mathrm{Bu}$ yorumlama sayesinde öğrenciden öğrendiklerini günlük yaşama transfer edebilmesi ve karşılaştığı sorunlara çözüm üretebilmesi beklenmektedir. Bu ortam oluşturulmadığı sürece sadece kuramsal bilgiler parça parça öğrenilmekte ve yaşantılarına katkı sağlayamamaktadır. Ayrıca disiplinlerarası yaklaşımı, disipline dayalı eğitimin bütünleştirme ve sorun çözme becerileri açısından daha yararlı ve seçenekli tamamlayıcısı olarak belirten Gür'e (2003) göre disiplinlerarası yaklaşım bireyin kendisini tanımasını, çevresinde olup bitenlerden haberdar olmasını ve değişimler yaratmasını sağlar. Bilgi alışverişine bağlı olarak farklı görüşleri dinleme 
gereksinimine yöneltir ve disiplinleri kendine özgü bakış açısıyla değerlendirebilme özelliği kazandırır (Gür, 2003).

Disiplinlerarası öğretim yaklaşımıyla ilgili yukarıda söz edilen açıklamalardan yola çıkarak disipliner yaklaşımın yok sayıldığı ya da daha gereksiz olduğu çıkarımı yapılmamalıdır (Yıldırım,1996). Çünkü kimi zaman bir konunun öğretiminde sadece kendi disiplin alanının doğasına ve yöntemlerine gereksinim duyulmaktadır. Disiplinlerarası yaklaşımlara dayalı programlar tek disiplinli yaklaşımdan daha fazla bilgi içerse de bütün konularda bütünleştirme yapmak olası değildir. Disiplinlerarası yaklaşımda, disiplinler arasında anlamlı ve uygun bilgiler varsa bütünleştirme yapılır. Diğer bir deyişle, disiplinler arasındaki bağlantılar güçlü ve kolay anlaşılır olmalıdır (Chrysostomou, 2004). Buna göre, okullarda her disipline özgü bir öğretme-öğrenme ortamının yanı sıra disiplinlerarası yaklaşıma dayalı öğrenme-öğretme ortamları da gerçekleştirilmelidir. Okullarda günümüz toplumunun istek ve gereksinimine uygun olarak yeni ders düzenlemelerinin oluşturulması, ders içeriklerinin de bu doğrultuda hazırlanması büyük önem taşımaktadır. Özçelik'e (2015) göre, 21. yüzyılın gereksinimleri doğrultusunda tek tip öğrenci yerine, farklı düşünebilme yeteneğine sahip öğrencilerin yetiştirilmesi gerekliliğinin yanı sıra gerek bilimsel gerekse teknolojik çalışmaların aynı anda birden çok disiplini kapsayacak biçimde yapılması, eğitim programlarında da değişikliğe gidilmesine neden olmaktadır.

Birçok bilim dalını içinde barındırdığından disiplinlerarası çalışmaların sergilendiği bilimlerin başında matematik gelmektedir. Matematik doğası gereği ardışık ve yığılmalı, varlıkların kendileriyle değil, aralarındaki ilişkilerle ilgilenen ve birçok bilim dalının kullandığı bir bilimdir (Bolat, Turna ve Keskin, 2012). Diğer bir deyişle matematikteki kavramlar birbiri üzerine kurulmuş, birbirleriyle ilişkili olmuş, önceki bilgi ve kavramlar ile kullanılmıştır (Bingölbali ve Coşkun, 2016). Birikimli bir şekilde gelişen bu bilim dalı, gelişim sürecinde hem kendi içinde birçok konu ile hem de farklı alanlarla bağlantılı olmuştur. Bu ilişkilendirmelerden dolayı matematiği birçok alanda görmek olanaklıdır. Gerek fen bilimlerinde gerekse ekonomi, sağlık ve hatta sanat dallarında (müzik, resim, süsleme) matematiği kapsayan noktalar bulunmaktadır.

Matematik öğretimi alanında uluslararası düzeyde kabul gören ve Milli Eğitim Bakanlığı'nın da 2005 Matematik Programlarından bu yana başvurduğu Ulusal Matematik Öğretmenleri Konseyi (National Council of Teacher of MathematicsNCTM) 2000 yılında Okul Matematiğinin İlkeleri ve Standartları (Principles and Standards of School Mathematics) başlıklı bir belge yayınlamıştır. Okulöncesi dönemden 12. sınıfin sonuna kadar matematiksel içerik ve süreçlerin hangi ölçünleri (standartları) sağlaması gerektiği açıklanan bu belgede, matematik eğitimi ile ilgili ölçünler, içerik ölçünleri ve süreç ölçünleri olmak üzere iki grupta toplanmaktadır. Süreç ölçünlerinde matematiksel ilişkilendirme becerisinin öğrencilere kazandırılması ile ilgili olarak üç madde yer almaktadır. Öğrencilerin;

1. Matematiksel fikirler arasındaki ilişkilerin farkına varıp bunları kullanmalar1, 
2. Matematiksel fikirlerin bir diğeriyle ilişkisinin ve bu ilişsilerle yeni düşüncelerin oluşturulup tutarlı bir bütün durumuna nasıl getirilebileceğini anlamaları,

3. Matematik dışındaki diğer disiplinlerle matematiği belirlemeleri ve uygulamaları beklenmektedir.

$\mathrm{Bu}$ maddelerden anlaşılacağı üzere, matematiksel ilişkilendirme sadece matematiğin kendi kavramları arasında değil, farklı disiplinlerle bir arada ele alınmakta, diğer bir deyişle disiplinlerarası anlayışa vurgu yapılmaktadır. 2005 ve 2013 yıllarında düzenlenen matematik öğretim programlarının amaçları arasında matematikle ilgili kavramlar, kavramların kendi aralarındaki ilişkileri, işlemlerin altında yatan anlam ve işlem becerilerinin kazandırılması da yer almaktadır. Süreç becerileri başlığında yer alan bu beceriler sorun çözme, matematiksel modelleme, iletişim kurma, akıl yürütme ve ilişkilendirme olarak belirtilmiştir (Milli Eğitim Bakanlığı-MEB, 2009, 2013). İlişkilendirme aşağıdaki şekilde açıklanmaktadır:

Matematikle diğer disiplinler ve gerçek hayat arasında ilişkiler bulunmaktadır. Sözü edilen ilişkilerin kullanılması için oluşturulan ortamlar, öğrencilerin matematiği daha rahat ve anlamlı öğrenmelerini sağlayacaktır. Bunun yanı sıra edinilen bilgi ve becerilerin kalıcılıkları artacak ve matematiğe yönelik olumlu tutuma sahip olabileceklerdir.

(MEB, 2013, s. 8)

Milli Eğitim Bakanlığı bu tanıma ek olarak ilişkilendirme becerisi kazandırılan öğrencilerdeki yeterlikleri maddeler biçiminde sıralamıştır. Bu maddelerden birisi de "Farklı disiplinlerde karşılaştığı problemleri matematik ile ilişkilendirerek çözme (matematiği diğer disiplinlerle ilişkilendirme)" (MEB, 2013, s. 9) olarak belirtilmiştir.

Matematik öğretim programlarında belirtilen ilişkilendirme kavramının NCTM'nin süreç ölçünlerinde yer alan ilişkilendirme kavramı ile örtüştüğü görülmektedir. 2017 programında ise ilişkilendirme becerisi, beceri alanları arasında yer almamaktadır. Bununla birlikte ilişkilendirme becerisine programın özellikle Öğrenme-öğretme süreci ve Ölçme ve değerlendirme başlıkları altında yer verildiği görülmektedir.

Matematiksel ilişkilendirme ile ilgili kavramsal bir çerçeve önerisinde bulunan Bingölbali ve Coşkun (2016), matematiksel ilişkilendirmenin dört ana bileşeni olduğunu belirtmektedir: (1) Kavramlar arası ilişskilendirme, (2) Kavramın farklı gösterimleri arasında ilişki kurma, (3) Gerçek yaşamla ilişkilendirme ve (4) Farklı disiplinlerle ilişkilendirme. Dördüncü bileşen olan farklı disiplinlerle ilişkilendirme, matematiğin diğer derslerle olan ilişkisini ön plana çıkaran bir beceri alanıdır. Dersin niteliğinin, kavramları iyi bilme ve bunlar arasında ilişki kurma ile bağlantılı olduğu da göz önüne alındığında, matematik eğitiminde ilişkilendirme kavramının önemli olduğu ortaya çıkmaktadır. Dersler arasında ilişki kurulması, bütüncül bir yaklaşımla bilgi ve beceri düzeyinde kazanımlara ulaşılmasına katkı sağlamakta, öğrencilerin üst düzey düşünme becerilerini geliştirmekte, öğrenmedeki aktarımlar için firsatlar 
sunmakta, bağımsız çalışmaya isteklendirmekte ve öğrencilerdeki öğrenme güdülenmesini de geliştirmektedir (Tchoshanov, 2011). Michelsen (2005) matematik ve diğer alanların ilişkisine önem veren araştırmaların sayısı arttıkça, söz gelişi, fizik ve matematik gibi alanların kavram ve süreçleri arasında daha fazla ilişki kurulduğunda, öğrencilerin konularla ilgili daha iyi bir kavrayışa sahip olacaklarını; dolayısıyla daha ilişkisel, etkili ve anlamlı öğrenmeler gerçekleşeceğini vurgulamaktadir.

Öte yandan, alanyazındaki tüm bu olumlu görüşlere karşın, ülkemizde disiplinlerarası çalışmalara yeterince önem verilmediği görülmektedir. Turna ve Bolat'ın (2015) eğitimde disiplinlerarası yaklaşımın kullanıldığı tezlerin çözümlemesini yaptıkları araştırmalarında, araştırmanın yayınlandığ 2015 yılına kadar 11'i Fen Eğitiminde olmak üzere toplamda 28 lisansüstü tezin bulunduğu belirtilmektedir. Araştırmacılar, Türkiye'de özellikle ortaöğretimde matematik, fen bilimleri ve yabancı dil gibi birçok alanla ilişkili kabul edilen derslerin, disipliner bir yaklaşımla öğretildiğini açıklamaktadırlar. Nitekim, ülkemizde son yıllarda yapılan çalışmalar matematik dersiyle diğer dersler arasında ilişki kurulmasına yönelik olarak hem öğretmenlerin hem de öğretmen adaylarının birtakım sorunlarla karşılaştığını ortaya koymaktadır. Karakuş ve Aslan (2016) ilkokulda disiplinlerarası öğretime yönelik mevcut durumu öğretmen görüşleri açısından inceledikleri çalışmalarında; öğretmenlerin bir kavramı, konuyu ya da temayı farklı disiplinlerle ilişkilendirmeye önem verdiklerini ancak zaman yetersizliği nedeniyle uygulayamadıklarını ortaya koymuştur. Aladağ ve Şahinkaya (2013) Sosyal Bilgiler ve Sınıf Öğretmenliği adaylarının sosyal bilgiler ve matematik derslerinin ilişkilendirilmesine yönelik yaptıkları çalışmalarında, öğretmen adaylarının ilişkilendirmenin yararlı olacağını düşündüklerini ancak bu ilişkilendirmenin nasıl yapılacağı konusunda bilgi eksiklikleri olduğunu otaya koymuşlardır. Coşkun (2013) matematik öğretmenleriyle gerçekleştirdiği yüksek lisans tezinde, matematik derslerinin işlenmesi sırasında ilişkilendirmeye çok az yer verildiğini ortaya koymuştur.

Bir programın başarısı onu uygulayan öğretmenlerin niteliği ve ders içi uygulamaları ile doğrudan ilişkili olduğundan, öğretmenlerin disiplinlerarası ders yaklaşımı ile ilgili bilgilerinin, düşüncelerinin ve yaptıkları uygulamaların önemli olduğu açıktır. $\mathrm{Bu}$ araştırma ile öğretmenlerin disiplinlerarası yaklaşım hakkında görüşlerinin ve dersteki uygulamalarının ortaya konulması amaçlanmıştır. Bu amaçla aşağıdaki sorulara yanıt aranmıştır:

1. Ortaöğretim matematik ve fen bilimleri (fizik, kimya, biyoloji) öğretmenlerinin disiplinlerarası öğretim yaklaşımı ile ilgili görüşleri nelerdir?

2. Ortaöğretim matematik ve fen bilimleri öğretmenlerinin Matematik ve fen bilimleri konuları arasında ilişki (bağlantı) olup olmadığına ilişkin görüşleri nelerdir? 
3. Ortaöğretim matematik ve fen bilimleri öğretmenlerinin, disiplinlerarası öğretim yaklaşımına ilişkin ders uygulamaları ne düzeydedir?

\section{Yöntem}

Bu bölümde araştırmanın modeli, çalışma grubu, veri toplama aracı ve verilerin çözümlenmesine ilişkin bilgilere yer verilmiştir.

\section{Araştırma Modeli}

$\mathrm{Bu}$ araştırmada nitel araştırma yöntemlerinden durum çalışması kullanılmıştır. Durum çalışması bir ya da daha fazla durum, olay, grup ya da programın incelenmesi, birbirine bağlı sistemlerin de aralarındaki ilişkinin ortaya konulmasını amaçlayan bir yöntemdir (Büyüköztürk, Çakmak, Akgün, Karadeniz ve Demirel, 2011). Bu araştırmada öğretmenlerin bakış açılarının ve dersteki uygulamalarının ortaya konulması amaçlandığından durumun çözümlenip ayrıntıların tanımlanması ve olaya ilişkin değerlendirmenin yapılmasının sağlanması için durum çalışması kullanılmıştır.

\section{Çalışma Grubu}

Çalışma grubunu 70 Matematik ve Fen Bilimleri öğretmeni oluşturmaktadır. Aynı programı yürütmeleri ve ders saatlerinin eşit olması nedeniyle araştırmada tek bir okul türüne odaklanmanın daha etkili sonuç vereceği düşünülerek Anadolu liselerinde görev yapan matematik ve fen bilimleri öğretmenlerinin görüşlerine başvurulmuş̧ur. Araştırmaya araştırmacıların da görev yaptı̆̆ı Marmara Bölgesinde yer alan İstanbul, Kocaeli, Sakarya ve Yalova illerindeki Anadolu liselerinde görev yapan 15 biyoloji, 9 fizik, 14 kimya ve 32 matematik öğretmeni katılmıştır. Katılımcıların görev süresi 2-32 yıl arasında değişmektedir.

\section{Veri Toplama Aracı}

Veri toplama aracı, araştırmacılar tarafından geliştirilmiş olan açık uçlu sorulardan oluşmaktadır. Veri toplama aracının geçerliğini sağlamak amacıyla alanyazına dayalı olarak hazırlanan sorular Kocaeli Üniversitesi Program Geliştirme ve Öğretim Anabilim Dalında görev yapan üç ve Ölçme ve Değerlendirme Anabilim Dalında görev yapan bir öğretim üyesinin görüşüne sunulmuştur. Ayrıca araştırmanın yöntem bölümü için nitel araştırma yöntemlerinde uzman bir akademisyenden görüş alınmıştır. 10 öğretmenle gerçekleştirilen pilot uygulama sonrası, ilk aşamada yer alan sekiz sorudan biri, katılımcılar tarafından net olarak anlaşılamadığı için (anlam bulanıklığı ya da karışıklığından kaynaklanan nedenlerle) veri toplama aracından çıkarılmıştır. Kavram yanılgısının ya da eksikliğinin ölçme aracının güvenirliğini düşürmemesi amacıyla, kavram konusunda netlik ve bütünlük sağlamak için veri toplama aracının giriş bölümüne disiplinlerarası kavramını açıklayan bir metin ve görsel eklenmiş̧tir. Anket formunda sorulan sorular aşağıda yer almaktadır:

1. Disiplinlerarası öğretim yaklaşımından ne anlıyorsunuz? 
2. Disiplinlerarası öğretim yaklaşımıyla öğrencilerin derse karşı tutum ya da akademik başarılarının olumlu yönde etkileneceğini düşünüyor musunuz? Neden/Neden değil?

3. Kendi dersinizin konuları ile matematik dersinin konuları arasında (Temel dört işlem becerileri hariç) ilişki (bağlantı) olduğunu düşünüyor musunuz? Neden/Neden değil? (Fen bilimleri öğretmenleri için) Kendi dersinizin konuları (Temel dört işlem becerileri hariç) ile fizik, kimya, biyoloji dersinin konuları arasında ilişki (bağlantı) olduğunu düşünüyor musunuz? Neden/Neden değil? (Matematik öğretmenleri için) (Üçüncü soruya yanıtınız olumsuz ise sonraki sorulara geçmeyiniz)

4. Matematik dersinin hangi konuları ile fizik, kimya, biyoloji dersinin hangi konularının ilişkili olduğunu düşünüyorsunuz? (Aşağıda verilen tablodaki konuları ilişkilendirerek yazınız).

5. Öğrencilerinizin dördüncü soruda seçmiş olduğunuz konuları sizden ya da başka bir kaynaktan yardım almadan ilişkilendirebildiklerini (ilişkilendirme becerisine sahip olduklarını) düşünüyor musunuz? Neden? Neden değil?

6. Derslerinizde disiplinlerarası öğretim yaklaşımını uyguluyor musunuz? Neden uyguluyorsunuz/Neden uygulamiyorsunuz?

7. Dördüncü soruda birbirleriyle ilişkili olduğunu ifade ettiğiniz konuları ilişkilendirerek örnek bir ders anlatımı oluşturabilir misiniz? Yanıtınızı aşağıdaki boşluğa yazabilirsiniz.

Anketteki birinci, ikinci ve beşinci sorular bu araştırmanın birinci araştırma sorusu ile; üçüncü ve dördüncü sorular ikinci araştırma sorusu ile; altıncı ve yedinci sorular üçüncü araştırma sorusu ile ilgilidir. İkinci, üçüncü, beşinci ve altıncı sorularda daha derinlemesine çözümleyebilmek için katılımcılara yanıtlarının gerekçeleri sorulmuş; katılımcıları belli bir yanıta yönlendirmemek için de hem "Neden?" hem de "Neden değil?" seçenekleri sunulmuştur. Üçüncü sorunun devamı niteliğinde olan dördüncü soru içinse, her dört disiplin alanının konularını kapsayan bir tablo hazırlanmış ve böylelikle katılımcıların programdaki konuları hatırlamaya çalışarak soruyu yanıtlaması yerine, doğrudan bu tablodan konuları seçmesi ve böylelikle araştırmanın güvenirliğinin artırılmasına çalışılmıştır. Tüm soruların yanıtları zaman sınırlamasını ortadan kaldırmak ve yanıtları derinlemesine alabilmek için katılımcılardan yazılı olarak istenmiştir.

\section{Verilerin Analizi}

Verilerin çözümlenmesinde nitel veri çözümleme yöntemlerinden içerik analizi kullanılmıştır. İçerik analizinde temel amaç, toplanan verileri açıklayabilecek kavramlara ve ilişkilere ulaşmaktır. $\mathrm{Bu}$ amaçla toplanan verilerin önce kavramlaştırılması, daha sonra da ortaya çıkan kavramlara göre mantıklı bir biçimde ve buna göre veriyi açıklayan temaların saptanması gerekmektedir. Bu doğrultuda bu çözümleme türünde temelde yapılan işlem, birbirine benzeyen verileri belirli kavram 
ve temalar çerçevesinde bir araya getirmek ve bunları okurun anlayabileceği bir biçimde düzenleyerek yorumlamaktır (Yıldırım ve Şimşek, 2016). Verilerin çözümlenmesi; 1) verilerin kodlanması, 2) temaların bulunması, 3) kodların ve temaların düzenlenmesi, 4) bulguların tanımlanması ve yorumlanması şeklinde dört aşamada gerçekleştirilmiştir. Verilerin kodlanması aşamasında; bütün veriler okunduktan sonra araştırmanın amacı çerçevesinde en çok yüklenen (atfetilen) kavramlara göre kodlama yapılmış ve kodlar arasındaki ilişkiler yorumlanmıştır. Katılımcılardan gelen anketlere numaralar verilmiş ve katılımcılar verilerin çözümlenmesi ve bulgular bölümlerinde bu numaralarla adlandırılmışlardır.

Veri çözümleme sürecinde, yapılan görüşmelerin yazılı metinlere dönüştürülmesinin ardından kodlar ve temalar iki araştırmacı tarafından ayrı ayrı oluşturulmuş ve karşılaştırmanın ardından farklılık gösteren kodlar uygun temalara atanmış ya da iptal edilmiştir (Miles ve Huberman, 1994). Oydaş olunan kodların toplam sayısının, görüş ayrımı yaşanan kodların toplam sayısına oranı hesaplanmış ve kodlayıcı güvenirliği puanı \% 82 olarak belirlenmiştir. Ayrıca araştırma sorularıyla ilgisi bulunmayan veriler ayıklanarak araştırma verilerine karışmalarının önüne geçilmiştir. Araştırmanın bazı bulgularının paylaşılması aşamasında, görüşmeye katılan öğretmenlerin anlatımlarına doğrudan alıntılar yapılarak yer verilmiştir.

\section{Bulgular}

Araştırmanın bu bölümünde veri çözümlemesinden sonra ortaya çıkan bulgulara yer verilmiştir.

\section{Araştırmanın Birinci Sorusuna Yönelik Bulgular}

Birinci maddede yer alan Disiplinlerarası öğretim yaklaşımından ne anlıyorsunuz? sorusuna gelen yanttlar incelendiğinde, en çok iki yanıtın yüklendiği görülmektedir. Katılımcıların büyük bir kısmı $(\mathrm{n}=58)$ disiplinlerarası öğretim yaklaşımını bir dersi/konuyu anlatırken farklı bir dersle/konuyla ilişki kurarak anlatmak diğer bir kısmı ise $(\mathrm{n}=12)$ dersi /konuyu bütüncül olarak anlatmak olarak tanımlamaktadırlar. Öğretmen yanıtlarında vurgulanan bir nokta ise ilişkilendirmenin bağlantılı konularla yapılması gerektiğidir. Aşağıda bazı yanıtlara yer verilmektedir:

"Bir dersin içindeki konunun farklı bir dersteki bağlantılı olduğu konu yardımıyla anlatılmasıdır" (9 no'lu katılımcı, Matematik öğretmeni, Mesleki deneyim: 8 yil).

"Alışılmış konuların (konu alanlarının) belirli kavramlar çerçevesinde bir araya getirilmesiyle oluşan bir yaklaşım. Farklı konu alanlarının birbirleriyle ilişkilendirilerek, bütünleştirilerek anlatıldığı bir öğretim şeklidir" (29 no'lu katılımcı, Matematik öğretmeni, Mesleki deneyim: 15 yil).

"Farklı isimli derslerde geçen ortak konuların birbirleriyle ilişkilendirilmesi" (21 no'lu katılımcı, Fizik öğretmeni, Mesleki deneyim: 32 yıl). 
İkinci maddede yer alan Disiplinlerarası öğretim yaklaşımıyla, öğrencilerin derse karşı tutumlarının ya da akademik başarılarının olumlu yönde etkileneceğini düşünüyor musunuz? Neden? Neden değil? sorusuna 70 öğretmenden yedisinin vermiş olduğu cevaplar sorunun içeriği ile örtüşmediğinden çözümlemeye alınmamıştır. Bu soruya olumsuz yanıt veren üç öğretmen gerekçe olarak okullarda çok daha önemli sorunlar olduğunu belirtmektedirler. Soruya olumlu yanıt veren 60 ögrretmenin yanıtları çözümlenmiş ve ortaya çıkan kodlar arasında ilişki kurularak Şekil 1'de belirtilmiştir (Bazı katılımcılar birden fazla yanıt vermişlerdir).

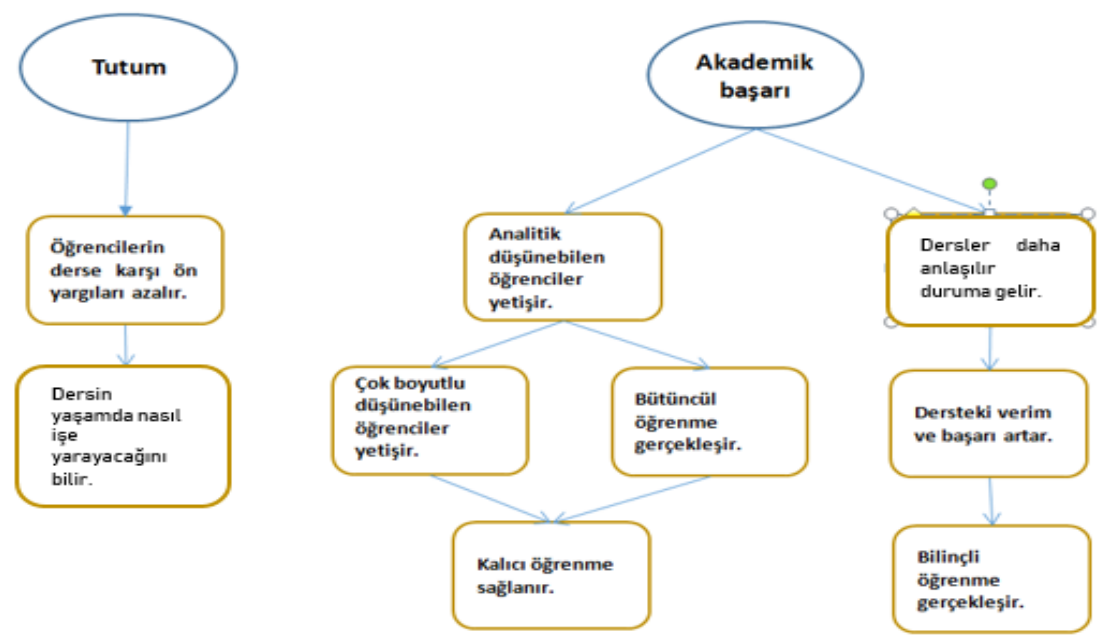

Şekil 1. Disiplinlerarası öğretim yaklaşımının öğrencilerin derse karşı tutumlarını ya da akademik başarılarını olumlu yönde etkileyip etkilemediğine ilişkin görüşler.

Şekil 1'de görüldüğü gibi araştırmaya katılan öğretmenler disiplinlerarası öğretimin öğrencinin hem derse karşı olan tutumunu hem de akademik başarısını olumlu yönde etkilediğini düşünmektedirler. Hem tutum hem de akademik başarı kategorisinde ele alınan yanıtlar birbirleriyle bağlantılı, diğer bir deyişle, birbirinin tamamlayıcısı ya da önkoşulu olarak kabul edilebilecek yanıtlardır. Aşağıda bazı yanıtlara yer verilmiştir:

"Daha bilinçli öğrenciler yetiştiren, daha etkileşimli bir sistem oluşacaktır. Kavram yanılgıları, yanlış öğrenmelerin aza indirgenebileceğini düşünüyorum” (10 no'lu katılımc1, Biyoloji öğretmeni, Mesleki deneyim: 2 yıl).

"Dersler arası, konular arası geçişler ve bağlantılar muhakeme gücünü arttırır" (63 no’lu katılımcı, Kimya öğretmeni, Mesleki deneyim: 10 yıl). 
"Bilginin bir bütün içinde anlamlı olduğunu düşünüyorum; diğer branşlardan kopuk bilgi aktarımı öğrencinin ancak kısa süreli hafızasında saklanabilir, kalıcı olmaz” (64 no’lu katılımc1, Biyoloji öğretmeni, Mesleki deneyim: 15 yıl).

"Hayatta ne işe yarayacak sorusunun önüne geçilebilir" (32 no'lu katılımcı, Matematik öğretmeni, Mesleki deneyim: 8 yil).

"Öncelikle matematik dersi sadece işlem ve motamot kuralların olduğu bir ders olmaktan çıkıyor. Konuya daha geniş açılardan bakmayı sağlıyor. Öğrencilerin günlük yaşantısında veya diğer derslerde gördükleri kavramlar ortaya çıkınca derse ilgileri artıyor ve daha çok katılım gösteriyorlar" (44 no'lu katılımcı, Matematik öğretmeni, Mesleki deneyim: 19 yıl).

Bazen matematikte bir konu çok detaylı gösteriliyor ve bu detay çocukları boğuyor. $\mathrm{O}$ zaman elde edilen bilgiyi sadece matematik olarak algıliyor fizik ya da başka dersle karşılaşınca kullanamıyor. $\mathrm{Bu}$ konudaki yaklaşımlar; öğrencide "bunu öğrenmeliyim, öğrenirsem şu tip soruları çözerim” yaklaşımı getirebilir. (55 no'lu katılımcı, Fizik öğretmeni, Mesleki deneyim: 20 yil)

Beşinci maddede yer alan Öğrencilerinizin dördüncü soruda seçmiş olduğunuz bu konuları sizden ya da başka bir kaynaktan yardım almadan ilişkilendirebildiklerini (ilişkilendirme becerisine sahip olduklarını) düşünüyor musunuz? Neden? Neden değil? sorusuna yanıt veren 70 katılımcıdan, soruya sadece Evet ya da Hayır şeklinde yanıt vermeyen 58 katılımcının yanıtı çözümlemeye alınmıştır. 18 katılımcı bu soruya olumlu, 40 katılımcı olumsuz yanıt vermişlerdir. Soruya olumlu yanıt veren katılımcıların yanıtları çözümlendiğinde tüm yanıtların aslında "Evet ama..." şeklinde belirtildiği görülmektedir. Katılımcılar kendi başlarına bu ilişkiyi kurabilen öğrencilerin var olduğunu ancak bunların her iki derste de akademik başarısı yüksek olan öğrenciler olduğunu açıklamaktadırlar. Soruya olumlu yanıt veren katılımcılar akademik başarısı yeterli düzeyde olmayan ve analitik düşünme becerisi yeterli olmayan öğrencilerin soru çözümünde bile öğretmene gereksinim duyduklarını vurgulamaktadırlar.

“... her sınıf her öğrenci düzeyi ve seviyesi farklı (bireysel farklılık). Bazı öğrencilerim biz bunu fizikte şu konuda da kullanıyoruz orada da anlatıldı diyen, kolaylık sağladı diyen bazı öğrenciler var" (69 no'lu katılımcı, Matematik öğretmeni, Mesleki deneyim: 9 yıl).

"Basit olan eşleştirmeleri yapabiliyorlar, farklı bağlantıları ilişkilendiremiyorlar fakat ben örnek verdikten sonra benzer örneklerle çoğaltabiliyorlar" (34 nolu katılımc1, Matematik öğretmeni, Mesleki deneyim: 6 yıl).

"Gerçekten her iki konuyu doğru anlamış olan öğrencinin bunu öğretmen belirtmese bile ilişkilendirme yapabileceğini düşünüyorum ki birkaç öğrencimle "bu işlemle ilgili soruları diğer derste de çözmüştük" yanıtını aldığım olmuştur" (10 no'lu katılımcı, Biyoloji öğretmeni, Mesleki deneyim: 4 yıl). 
Soruya olumsuz yanıt veren katılımcıların yanıtları çözümlendiğinde yanıtların benzer noktalarda toplandığı görülmektedir: Sadece o anda öğrendikleri konuya odaklanmaları, ilkokul ve ortaokulda analitik düşünme yeteneklerinin gelişmemesi, sınav odaklı çalışmaları, ezbere dayalı çalışmaları.

"Eğitim sistemimizin öğrencilerimizi düşünmeye, araştırmaya ve sorgulamaya ve kendi kendine öğrenmeye yönlendirmiyor. Öğrencilerimiz konu tekrarlarını bile öğretmen eşliğinde yapıyor” (52 no'lu katılımcı, Matematik öğretmeni, Mesleki deneyim: 12 yil).

"Ezbere alışmış öğrenciler, matematikte kullanılan üçgen ile fizikte kullanılan üçgenin aynı olduğunu fark edemiyorlar. En ufak bir değişiklikte kilitlenip kalıyorlar" (55 no’lu katılımcı, Fizik öğretmeni, Mesleki deneyim: 20 yıl).

"Ayrı ayrı öğrenebilirler belki ama öğrendikleri bilgileri harmanlamada kesinlikle bir kaynağa gereksinimları var” (8 no'lu katılımcı, Biyoloji öğretmeni, Mesleki deneyim: 14 yıl).

“...temel matematik becerilerini kazanamamıș bir öğrenci bir fizik sorusu çözerken, çözüm sırasında yaşadığı zorluğun matematik becerilerinin eksik olmasından kaynaklandığını ne yazık ki fark edemiyor" (14 no'lu katılımcı, Fizik öğretmeni, Mesleki deneyim: 15 yıl).

Araştırmanın birinci sorusuna ilişkin bulgulara bakıldığında çalışmaya katılan öğretmenlerin disiplinlerarası öğretim yaklaşımı konusunda kavramsal düzeyde bilgi sahibi oldukları söylenebilir. Çalışmaya katılan öğretmenler disiplinlerarası öğretimi bir dersi/konuyu anlatırken farklı bir dersle/konuyla ilişki kurarak anlatmak; bütüncül olarak anlatmak, diğer disiplinlerle bağlantılı olarak anlatma çabası olarak belirtmektedirler.

Katılımcılar büyük oranda disiplinlerarası öğretimin öğrencilerin akademik başarısını ve tutumunu olumlu yönde geliştirdiğini düşünmektedirler. Verilen yanıtlar ele alındığında akademik başarı ile ilgili yanıtlar iki boyutta toplanabilir: Analitik düşünen öğrencilerin yetişmesi ve derslerin daha etkili/anlaşılır olması. Bütünlüklü, çok boyutlu ve dolayısıyla analitik düşünen bireylerin yetişmesine katkı sağlayacağından öğrenmeler de kalıcı duruma gelecektir. İkinci boyutta ise disiplinlerarası öğretimle daha etkili ve anlaşılır derslerin işlenmesiyle derslerdeki verim ve başarı artacak ve böylelikle bilinçli öğrenci yetişecektir. Tutum açısından incelendiğinde ise matematik dersine ilişkin olumsuz önyargıların kırılmasıyla öğrendiklerinin yaşamda ne işe yarayacağının da farkına varmış olacaklardır.

Araştırmada katılımcıların büyük bir çoğunluğu bir başka kaynaktan destek almadan öğrencilerin ilişkilendirme yapmakta güçlük çektiklerini belirtmektedir. Bunun nedenleri arasında var olan eğitim sisteminin bu beceriyi sağlayamadığı, öğrencilerin sadece gördükleri derse ve konuya odaklı çalıştıkları ve sınav odaklı hareket ettikleri şeklinde açıklanmaktadır. Soruya olumlu yanıt veren öğretmenler de 
ilişkilendirmeyi yardım almadan/bağımsız olarak yapabilen öğrencilerin ancak her iki konuya da hakim olan başarılı öğrenciler olduğunu vurgulamaktadır.

\section{Araştırmanın İkinci Sorusuna Yönelik Bulgular}

Üçüncü maddede yer alan Matematik dersinin konuları (temel dört işlem becerisi hariç) ile fizik/kimya/biyoloji dersinin konuları arasında bir ilişki/bağlantı olduğunu düşünüyor musunuz? sorusu için yapılan çözümlemede olumlu yanıt veren 70 katılımcının yanıtları çözümlenerek Tablo 1'e yerleştirilmiştir. (Bazı katılımcılar birden fazla yanıt vermişlerdir.)

Tablo 1

Matematik ve Fen Bilimleri Arasındaki İlişki

\begin{tabular}{llc}
\hline \multicolumn{1}{c}{ Katılımeı Yanıtları (70) } & \multicolumn{1}{c}{ Kodlar } & Sıklık \\
\hline & $\begin{array}{l}\text { Fizik ve kimya derslerinin içerisinde birçok } \\
\text { yerde matematik kullanılması }\end{array}$ & 55 \\
Matematik ve fen dersleri & $\begin{array}{l}\text { Matematiğin evrensel bir dil olması / her yerde } \\
\text { kullanılması }\end{array}$ & 52 \\
& $\begin{array}{l}\text { Sosyal bilimler de dahil tüm bilimlerin } \\
\text { merkezinde matematiğin olması }\end{array}$ & 49 \\
\hline
\end{tabular}

Tablo 1'de görüldüğü gibi, üçüncü maddeye verilen yanıtlar çözümlendiğinde katılımcıların büyük çoğunluğu, matematik öğretmenlerinin de neredeyse tamamı, matematiği sadece fen bilimleri ile değil tüm derslerle ilişkili kabul etmekte; matematiği evrensel bir disiplin olarak ele almaktadırlar.

"Matematik sadece doğayı anlamak için değil, insan davranışlarını, sosyal olayları anlamak için de bir araçtır” (18 No'lu katılımcı, Matematik öğretmeni, Mesleki deneyim: 4 yıl).

"Tüm bilimlerin temelinin geometri ve matematik olduğu gerçeğinden hareketle öğrencilerin analitik düşünme becerilerinin geliştirilmesi için fizik, kimya ve biyoloji derslerinde öğrenme sürecini kolaylaştıracaktır. Hatta sözel derslerde bile düşünme sürecinde etkili olacaktır" (56 no'lu katılımcı, Matematik öğretmeni- Mesleki deneyim: 20 yil).

"Özellikle Fen derslerinin birbirleriyle birçok alanda bağlantısı var. Doğanın oluşumu fen dersleriyle açıllansa da bu işin sayısal verileri de matematikle açıklanır. Bu yüzden de matematiğin bu derslerin kendiliğinden bir parçası olması kaçınılamaz" (33 no'lu katılımc1, Matematik öğretmeni, Mesleki deneyim: 5 yıl).

"Fizik dersi matematik dersi başta olmak üzere tüm derslerle ilişkilidir. Fizik dersinde öğrencilerin pozitif düşüncelerini geliştirerek, yorum yapabilme, günlük hayatla ilişki kurma, analitik düşünebilmeleri için dersler arasında özellikle matematik dersi ile bağlantı kurmaları gerekir" (35 no'lu katılımcı, Fizik öğretmeni, Mesleki deneyim: 31 yll). 
$\mathrm{Bu}$ soruya yanıt veren öğretmenlerin yarıya yakını (n: 34) bu soruyu örneklendirerek yanıtlamışlardır. Aşağıda bu örneklerden bazıları yer almaktadır:

“.....̈̈ç boyutlu cisimlerin alan ve hacimleri fizikte, karışım problemlerinin kimya da çözelti konusuyla, gen diziliminin sıralama ile ilişkisi vardır” (47 no’lu katılımcı, Matematik öğretmeni, Mesleki deneyim: 3 yıl).

“....Örneğin tıp alanında değerlerin sayılarla ifade edilebilmesi, fizikteki optik, atış konuları vs. matematikle ilişkilidir" (49 no'lu katılımcı, Matematik öğretmeni, Mesleki deneyim: 4 yil)

"Fizik öğretmenleri hız-zaman grafiğinin altında kalan alanının yolu verdiğini ifade ediyorlar. Biz matematikçiler de hızın integralinin yol olduğunu, integralin eğri altında kalan alan olduğunu ifade ediyoruz" (52 No'lu katılımc1, Matematik öğretmeni, Mesleki deneyim: 12 y1l).

“Öğrenci dersi sadece matematik terimleri ile öğrenmek istemiyor. Bir açıortay terimini anlatırken kalbe benzerliği dikkati çekiyor. Sadece fizik, kimya, biyoloji değil müzik, çizgi film kahramanları kullanılması da farklılık katıyor"' (28 no'lu katılımcı, Matematik öğretmeni, Mesleki deneyim: 6 yıl).

Ayrıca, bazı fen bilimleri öğretmenleri matematik dersindeki başarı ya da başarısızlığın kendi derslerini de doğrudan etkilediğini belirtmektedirler.

“ph - poH kavramları ile ilgili çalışırken logaritmayı, grafikte altta kalan alanı hesaplarken geometriyi kullanmamız gerekiyor. Üslü, köklü sayıları, oran-orantı problemlerini sıkça kullanıyoruz. Matematik ve işlem becerisi düşük olan öğrencilerin zorlandıkları veya kimya dersini yeterince anlamadıklarına da şahit oluyoruz" (70 no'lu katılımc1, Kimya öğretmeni, Mesleki deneyim: 12 yıl).

"Kimya dersi de matematik dersi gibi analitik düşünme becerisi gerektiriyor. Yorum yapma, üç boyutlu düşünme, logaritma gibi matematiksel ifadeleri bilmeden kimya dersinde başarı elde edemeyeceğini düşünüyorum" (31 no'lu katılımc1, Kimya ögretmeni, Mesleki deneyim: 5 y1l).

"Fizik matematik temelli bir derstir, Yani doğa olaylarının matematiksel ifadesidir fizik. Fizik dersini yapabilmesi için öğrencilerin matematik bilmesi gerekir" (59 no'lu katılımc1, Fizik öğretmeni, Mesleki deneyim: 12 yıl).

"Fizik, içerisinde çok fazla matematiksel kavram barındıran bir ders. Fizik öğretimi için disiplinlerarası yaklaşım bir tercih değil zorunluluktur” (41 No’lu katılımcı, Fizik öğretmeni, Mesleki deneyim: 5 yıl).

Dördüncü maddede yer alan Matematik dersi ile fizik / kimya / biyoloji dersleri arasında ilişkili olduğunu düşündüğünüz konular hangileridir? sorusuna 70 katılımcıdan 14'ü yanıt vermemişlerdir. 56 katılımcının yanıtları çözümlenerek sonuçlar Tablo 2'ye yerleştirilmiştir. 
Tablo 2

Matematik Dersinin Konularının Fizik/Kimya/Biyoloji Derslerinin Konularl İe İlişkisi

\begin{tabular}{ll}
\hline En Çok İlişki Kurulan Konular & Disiplin Alanları (Frekanslar) \\
\hline Türev--Doğrusal hareket & Matematik (10)-Fizik (7) \\
İntegral--Doğrusal hareket & Matematik (6)-Fizik (3) \\
Hız problemleri--Doğrusal hareket & Matematik (4)-Fizik (3) \\
Trigonometri--Kuvvet, tork denge & Matematik (6)-Fizik (5) \\
1. dereceden denklemler--Isı ve sıcaklık & Matematik (1)-Kimya (3) \\
Logaritma--Asitler-bazlar & Matematik (3)-Kimya (3) \\
Üslü sayılar--Kimyasal denge & Matematik (2)-Kimya (7) \\
Oran-orantı--Gazlar & Matematik (0)-Kimya (4) \\
Oran-orantı--Mol kavramı & Matematik (0)-Kimya (4) \\
Oran-orantı--Kimyasal denklemler & Matematik (0)-Kimya (3) \\
Oran-orantı--Kimyasal hesaplamalar & Matematik (0)-Kimya (3) \\
Olasılık--Genetik/kalıtım & Matematik (0)-Biyoloji (12) \\
\hline
\end{tabular}

Tablo 2'de görüldüğü gibi araştırmaya katılan matematik öğretmenlerinin matematik dersini en ilişkili kabul ettikleri ders fizik, en az ilişkili kabul ettikleri ders ise biyolojidir. Ayrıca, matematik öğretmenlerinin matematik ile ilişkili görmedikleri bazı kimya ve biyoloji konuları ilgili alan öğretmenlerince ilişkili kabul edilmektedir.

Araştırmanın ikinci sorusuna ilişkin bulgulara genel olarak bakıldığında katılımcıların matematik dersini sözel dersler de dahil olmak üzere tüm derslerle ilişkili gördükleri hatta matematiğin tüm bilimlerin merkezinde yer alan evrensel bir disiplin olarak kabul ettikleri görülmektedir. Matematik öğretmenlerinin matematik dersi ile en ilişkili kabul ettiği ders, fizik dersi olarak ortaya çıkmaktadır. Kimya ve biyoloji öğretmenleri matematiği tüm bilimlerin temelinde ve kendi dersleriyle ilişkili olarak belirtse de en çok Fizik öğretmenlerinin matematiği fizik dersinin olmazsa olmazı olarak kabul ettiği görülmektedir. Bu noktada Matematik ve Fen Bilimleri öğretmenlerinin yanıtlarının birbirleriyle tutarlı olduğu söylenebilir.

Katılımcılara göre fizik dersi ile en ilişkili matematik konuları oran, orantı, türev, trigonometri, integral ve hız problemleri iken kimya dersi ile en ilişkili kabul edilen matematik konuları ise oran, orantı, logaritma, üslü sayılar ve karışım problemleridir. Konular arasında daha doğrudan ilişki kurulduğunda ise, matematikteki türev konusu ile fizikteki doğrusal hareket; matematikteki üslü sayılar ile fizikteki kimyasal denge; matematikteki olasılık konusu ile biyolojideki kalıtım/genetik konusu arasında daha güçlü bağlantı olduğu belirtilmektedir. Bu noktada en göze çarpan ise matematik ve kimya; matematik ve fizik öğretmenlerinin kendi alanlarıyla ilişkili konular hakkındaki görüşlerinin büyük oranda birbirlerine yakın olduğudur. Sadece biyoloji dersi açısından matematik ve biyoloji öğretmenlerinin yanıtları arasında büyük farklılık olduğu görülmektedir. Biyoloji öğretmenleri biyolojideki genetik/kalıtım konusuyla matematikteki olasılık konusunu ilişkili kabul ederken matematik öğretmenlerinden bu ilişkiyi kuran olmamıştır. 


\section{Araştırmanın Üçüncü Sorusuna İlişkin Bulgular}

Altıncı maddede yer alan Derslerinizde disiplinlerarası yaklaşımı uyguluyor musunuz? Neden uyguluyorsunuz?/Neden uygulamıyorsunuz? sorusunu beş katılımcı boş bırakmış, beş katılımcı ise sadece Evet ya da Hayır şeklinde yanıt vermiş̧ir. Soruya yanıt veren 60 katılımcıdan 16'sının vermiş olduğu yanıtlar sorunun içeriği ile örtüşmediğinden çözümlemeye katılmamıştır. 44 katılımcıdan 30 'u bu soruya olumlu, dokuzu ise olumsuz yanıt vermişlerdir. Beş katılımcı ise sınırlı olarak uyguladıklarını ya da farkında olmadıklarını belirtmektedirler. Soruya olumlu yanıt veren katılımcılardan gelen cevapların analizi yapıldığında en çok yüklenen yanıtlar belli temalar altında kodlanmış ve yanıtlara göre birbirleriyle ilişkilendirilmiş̧tir.

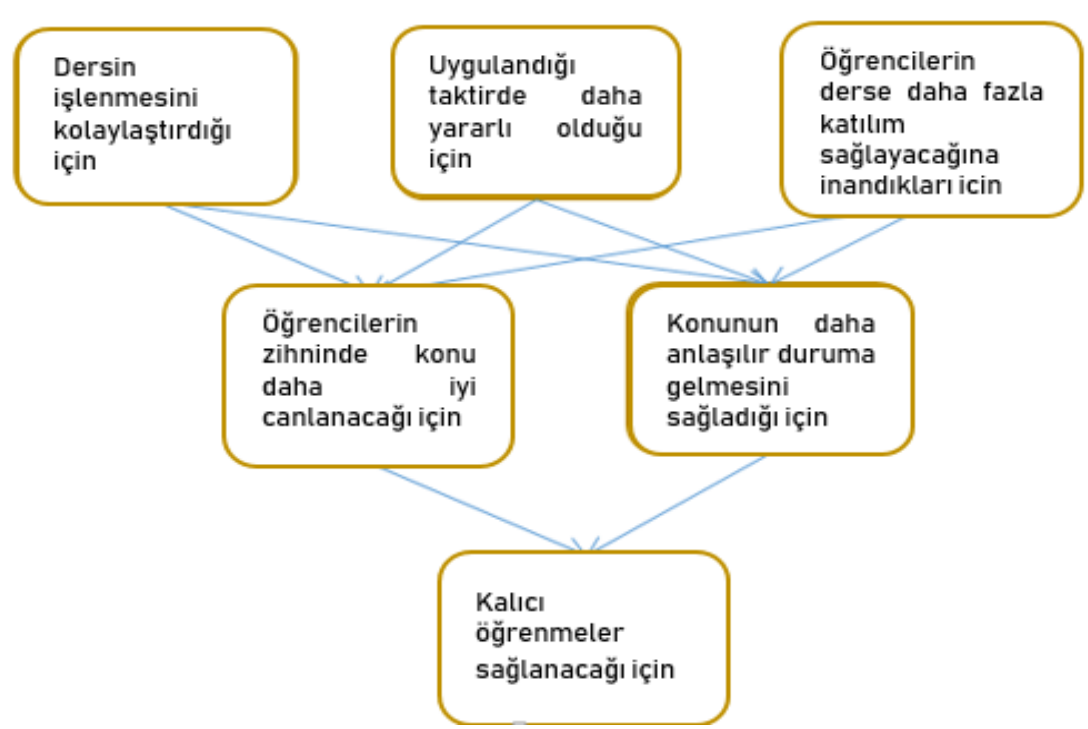

Şekil 2. Öğretmenlerin derslerinde disiplinlerarası uygulamalara yer verme durumları

Şekil 2'de de görüldüğü üzere katılımcılar derslerin işlenmesini kolaylaştırıp öğrencilerin derse katılımını sağladığından hem konunun öğrencinin zihninde daha iyi canlandığını hem de daha anlaşılır duruma geldiğini ve böylelikle kalıcı öğrenmeler sağlandığını düşündüklerinden derslerinde disiplinlerarası öğretime yer vermektedirler. Bazı katılımcıların yanıtları aşağıda yer almaktadır.

... çünkü bilginin bir bütün olduğunu düşünüyorum, diğer bilim dallarından bağımsız bir şekilde ilerleme çok yavaş olur. O yüzden çok iyi fizikçiler aynı zamanda matematikçidir. Özellikle bizim branşımızda biyomedikal, biyomühendislik, biyokimya gibi alt branşlar, diğer bilimleri 
de kullanarak yeni ufuklar açabiliyor. (64 no'lu katılımcı, Biyoloji öğretmeni, Mesleki deneyim: 15 yıl)

“...bu şekilde öğrencilere her derste birbirinden bağımsız şeyler öğrenmediklerini, tüm bilgileri bir araya getirdiklerinde bilimde her bilginin evrensel olduğunu göstermeye çalışıyorum" (70 no'lu katılımcı, Kimya öğretmeni, Mesleki deneyim: 12 y1l).

“Tekrarın bir konunun öğrenilmesi ve kalıcılı̆̆ını artırması açısından en önemli faktör olduğunu düşünüyorum. Disiplinlerarası yaklaşım bir bakıma tekrar oluyor ve aynı kavrama farklı bakış açılarıyla yaklaşılmasını sağlıyor" (31 no'lu katılımcı, Kimya öğretmeni, Mesleki deneyim: 5 y1l).

Soruya olumlu yanıt veren bazı katılımcılar bireysel olarak derslerinde bu ögretimi uyguladıklarını ancak bunun sistematik ve planlı bir hale gelmesi ve eğitim programlarının buna uygun olması gerektiğini belirtmektedirler.

(...) Öğretmenler olarak her öğretim yılının başında hazırladı̆̆ımız araştırma planlarında diğer zümre öğretmenleriyle işbirliği sütununda bu yaklaşımı kağıt üzerinde ifade ederiz. Ancak, derslerimiz işlenirken bizim gereksinim duyduğumuz bir matematiksel bilginin karşıllı̆g örneğin 11. Sınıflarda logaritma kavramı, matematik dersinin planı içinde o yıl karşılık bulmaz. Ya da sıralanma biçimi eşlenmez. Finlandiya'da bu yöntemin bütünüyle uygulanmaya başlandığı ile ilgili bir makale okumuştum. Orada sistem konuları derslere hapsetmiyor, söz gelişi genleşme işlenirken eş zamanlarda kimya-fizik-matematik kendi içeriğiyle destek sunuyor. (23 no'lu katılımcı, Kimya öğretmeni, Mesleki deneyim: 26 yıl)

(...) fakat disiplinlerarası yaklaşım çift yönlü ve (bence) önceden yapılan bir planlama doğrultusunda olmalı. Açıkçası bu yönünün eksik olması tam bir uygulama yapamadığımızı gösterir. $\mathrm{Bu}$ anlamda okulumuzda sene başında konuşarak çeşitli konuları birbirine uyumlu olacak şekilde düzenliyoruz özellikle Fizik ve matematik dersi için. (44 no'lu katılımcı, Matematik öğretmeni, Mesleki deneyim: 19 yıl)

(...) bu konudaki sıkıntı bence disiplinlerarasından çok ortaokul müfredatı ve öğrenciye aktarılması, kazandırılması gereken özelliklerin pas geçilmesi. Ortaokul müfredatını inceleyin, problem çözme ve denklem kurma becerisi geliştirilmiyor. Çocuklar sayı deyince sadece tam sayı var zannediyor. ...Fizikte işlem yapamadığı için doğru sonuca ulaşamayan o kadar çok çocuk var ki. (55 no'lu katılımcı, Fizik öğretmeni, Mesleki deneyim: 20 yil)

Soruya olumsuz yanıt veren dokuz katılımcının gerekçesi temelde üç nedene dayanmaktadır: Derse ayrılan sürenin kısıtlı olması, eğitim programının yoğun olması ve öğrencilerin bu ilişkilendirmeyi yapmada yetersiz olması. Buna göre derslerinde bu yaklaşıma dayalı öğretimi kullanmayan öğretmenlerin disiplinlerarası ders 
öğretimini fazlaca zaman gerektiren ve program dışı etkinlik olarak ele aldıkları söylenebilir.

Altıncı maddede katılımcılardan ders içi uygulamalarına dönük bir ders anlatımı yapmaları istenmiştir ancak disiplinlerarası öğretimi derslerinde uyguladıklarını belirten 30 katılımcıdan sadece 19'u bu soruya yanıt vermiştir. Soruya yanıt veren 19 katılımcının 15'inin hizmet süresi 12 yıl ve üstüdür. Katılımcılardan üçü sadece kendi derslerindeki hangi konunun diğer dersteki hangi konularla ilişkili olduğunu yazdıkları ancak ders planı oluşturmadıkları için analize tabi tutulmamıştır. 16 katılımcidan altı katılıme bu soruya merkeze bir konu alarak hangi alanlarla ilişkilendirme yapılabileceğine ilişkin şemalar çizmişler ancak nasıl bir ders tasarladıklarını belirtmemişlerdir. Bu tür yanıtlarla ilgili bir örnek Şekil 3’te yer almaktadır:

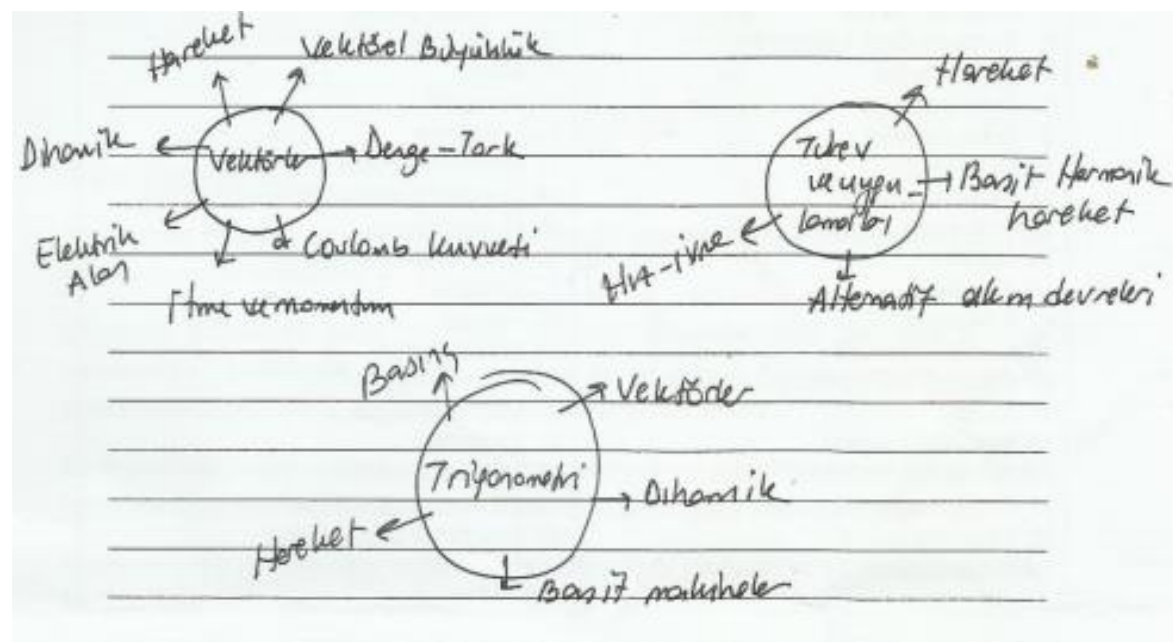

Şekil 3. Merkeze bir konu alarak hangi alanlarla ilişkilendirme yapılabileceğine ilişkin çizilen şemalardan bir örnek (35 no'lu katılımcı, Fizik öğretmeni, Mesleki deneyim: 32 yil)

Şekil 3’te görüldüğü gibi 35 numaralı katılımcı merkeze vektör, türev ve trigonometri konularını alarak fizik dersindeki ilişkili konuları sıralamış ancak örnek bir ders hazırlamamıştır.

Soruya yanıt veren on öğretmenden sekizi derslerinde örnekler verirken işledikleri konuyla ilgili benzetimlerden ya da soru çözümlerinde ilgili alanlardan yararlandığını belirtmektedir.

"Üslü sayıları anlatırken ülkelerin nüfus artış hızlarından ve popülasyon ile üslü sayılar arasındaki ilişkilerden söz ediyorum. Kalkülüs anlatırken felsefi olarak 
irdelemek için sonsuzluk kavramı ile ilgili tartışma yaptırıyorum" (18 no'lu katılımcı, Matematik öğretmeni, Mesleki deneyim: 2 yıl).

“...EKG sinyallerinin incelenmesi ile ilgili bir konu okumuştum. ORS dalgalarının kalp tansiyonunun ve kalp ritminin matematiksel programlar yardımıyla hesaplandığını söyleyip derse ilgi çekerim" (1 no'lu katılımcı, Matematik öğretmeniMesleki deneyim: 3 yil).

“...Denklem çözerken eşitliği bir köprüye benzetmek köprüden sayı geçirirken bir şarkı ile ilişkilendirmek...” (28 n’olu katılımcı, Matematik öğretmeni, Mesleki deneyim belirtilmemiş).

“...işlem sırası adlı matematik konusunu işlerken aynı anda bir deneyin işlem sıralarını, tepkime sıralarını anlatarak örneklendiriyorum" (68 no'lu katılıme, Matematik öğretmeni, Mesleki deneyim: 19 yıl).

“...Bitkilerde suyun taşınmasında adezyon-kohezyon kuvveti fizikle ilişkilendiriyorum” (64 no’lu katılımcı, Biyoloji öğretmeni, Mesleki deneyim: 15 yıl).

"Gazlarda yayılma hızı mol ağırlıklarının karekökü ile ters orantılıdır. Bu kavram anlatılırken hem köklü ifadelerde bölme- sadeleşme hem de orantı kavramlarını hatırlatıyorum” (31 no'lu katılımcı, Kimya öğretmeni, Mesleki deneyim: 5 yil).

“... Değişim olan her şeyde türev vardır diyerek ilişkilendirmeye başlarım. Türev kimyada tepkime hızı, reaksiyon hızı ve kimyasal bağlarla; fizikte hareket ve kuvvetle; biyolojide büyüme ile ve ekonomide enflasyonla ilgilidir diye örnek veririm" (34 no'lu katılımc1, Matematik öğretmeni, Mesleki deneyim: 6 yıl).

“...yeni işleyeceğim veya tanıtacağım bir kavramla ilgili diğer disiplinlerden örnekler vererek derse başlıyorum veya bu kavramı örneğin Fizikte nasıl ve ne için kullanıyorsunuz gibi sorular yöneltiyorum. Konu sonunda seçtiğim problemlerin diğer disiplinlerle ilişkili olmasına özen gösteriyorum" (44 no'lu katılımcı, Matematik öğretmeni, Mesleki deneyim: 19 yll).

İki katılımcı ise disiplinlerarası bir dersi nasıl tasarladıklarına ilişkin yanıt vermişlerdir. Şekil 4 'te bir fizik öğretmenin yanıtı verilmiştir. 


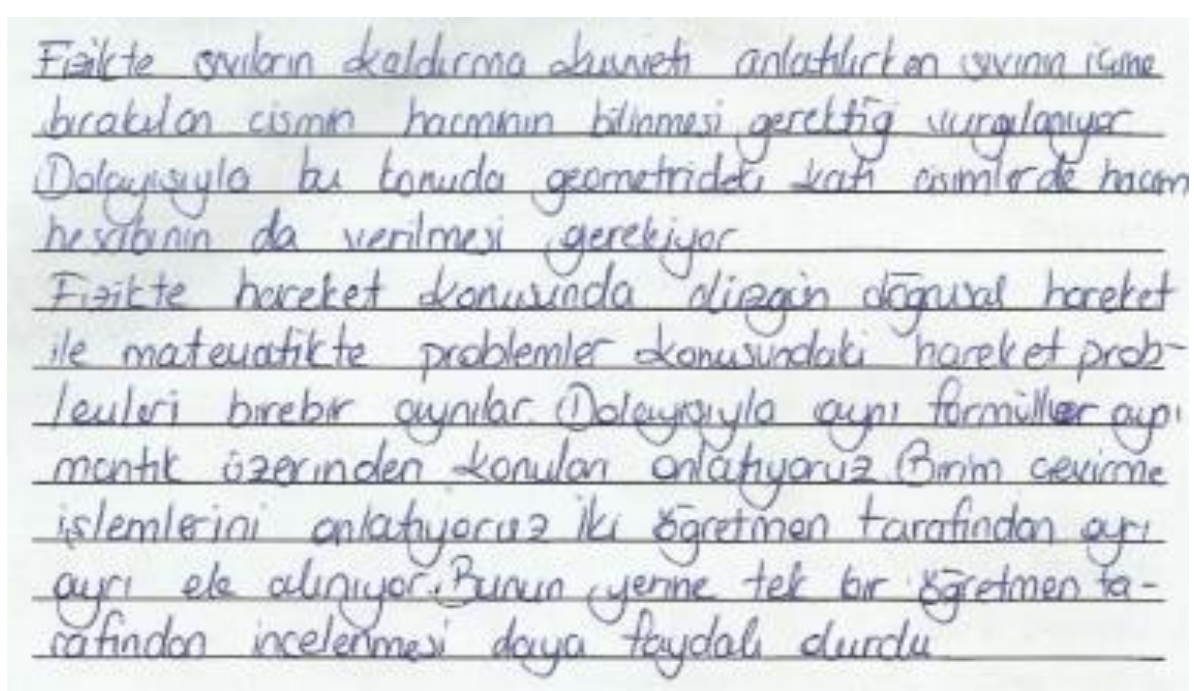

Şekil 4. Disiplinler arası yaklaşımla ders tasarımı için bir öneri (52 no'lu katılımcı, Fizik öğretmeni, Mesleki deneyim: 12 yıl).

Şekil 4'te görüldüğü üzere 52 numaralı katılımcı ders tasarımında fizik dersi ile matematik dersini ilişkilendirmiştir. Bu ilişkilendirmeyi yaparken konu örnekleri üzerinden gitmiştir. Fizik dersindeki kaldırma kuvveti konusunun anlaşılabilmesi için geometrik cisimlerin hacimlerinin bilinmesi gerektiğini vurgulamış ve fizik dersindeki doğrusal hareket konusu ile matematik dersindeki hareket konusunun aslında aynı konular olduğunu belirtmiştir. Burdan yola çıkarak derslerin ilgili konuları arasında bir bütünleştirme yapılarak, tek bir öğretmen tarafından konunun verilmesini önermiştir.

Disiplinlerarası ders tasarımının nasıl yapılması gerektiğine yönelik bir diğer öneri de 55 numaralı katılımcıdan gelmiştir. Şekil 5 'te katılımcının verdiği yanıt gösterilmektedir. 


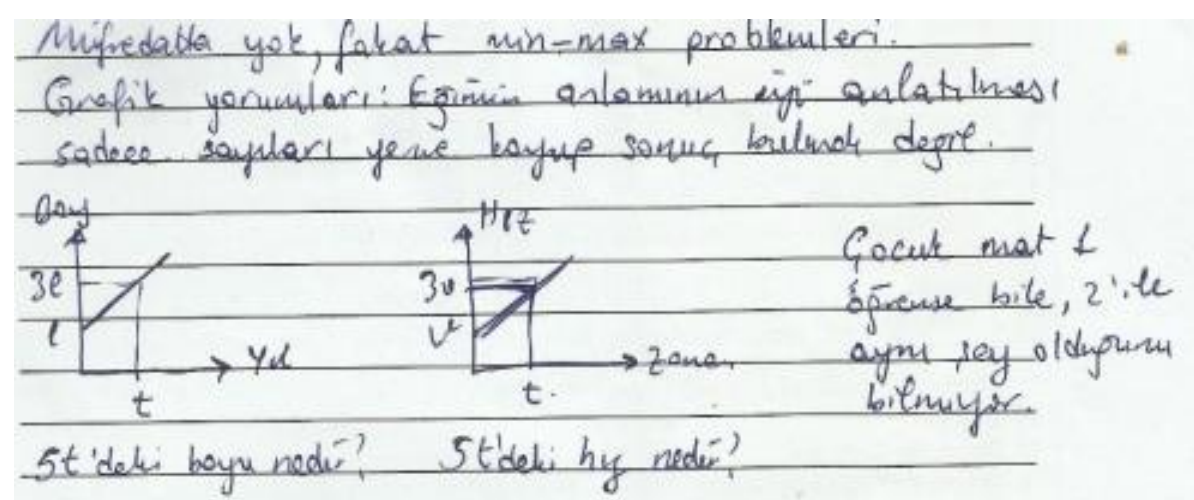

Şekil 5. Disiplinler arası yaklaşımla ders tasarımı için bir öneri (55 no'lu katılımcı, Fizik öğretmeni, Mesleki deneyim: 20 yıl).

Şekil 5'te görüldüğü üzere Fizik Öğretmeni olan 55 numaralı katılımcı disiplinlerarası ders tasarımı için örnekli bir anlatım yapmıştır. Katılımcının vermiş olduğu örnekte, öğrencilerin matematik dersinde öğrenmiş olduğu grafik konusu fizik dersindeki boy ve hız konuları üzerinden anlatılmaktadır.

\section{Tartışma, Sonuç ve Öneriler}

Disiplinlerarası öğretim yaklaşımına ilişkin matematik ve fen öğretmenlerinin görüşleri ve ders içi uygulamalarına dayanan bu araştırmada birinci araştırma sorusu öğretmenlerin disiplinlerarası öğretim yaklaşımları ile ilgili görüşlerine, ikinci sorusu hangi konular arasında ilişki kurduklarına ve üçüncü sorusu ise ders uygulamalarına dönüktür. Birinci araştırma sorusuna dönük olarak ortaya çıkan ilk sonuç öğretmenlerin kavramsal olarak konu hakkında bilgi sahibi olduklarıdır. Öğretmenlerin disiplinlerarası kavramını bir konunun öğretiminde diğer derslerle ilişki kurma ya da bütünlüklü anlatma şeklindeki ifadeleri Aydın ve Balım (2005), Yalçın (2013) ve Yıldırım'ın (1996) kavrama ilişkin yaptıkları tanımlarla örtüşmektedir.

Birinci araştırma sorusuna dönük olarak ortaya çıkan ikinci sonuç ise öğretmenlerin disiplinlerarası öğretimi öğrencilerin akademik başarısını arttırmada ve derse ilişkin olumlu tutum geliştirmede etkili bulduklarıdır. Diğer bir deyişle katılımcılar, disiplinlerarası yaklaşımla yapılan öğretimi öğrencilerin hem bilişsel hem de duyuşsal becerilerini geliştirdiğini düşünmektedirler. Bu sonuç, Karakuş ve Aslan'ın (2016) ilkokul öğretmenlerinin disiplinlerarası ilişkilendirmeye önem verdiklerini ortaya koyan araştırmalarının sonuçlarıyla paralellik göstermektedir. Ayrıca araştırmaya katılan öğretmenlerin büyük bir çoğunluğu, öğrencilerin öğretmen desteği olmadan ilişkilendirme yapmakta güçlük çektiklerini düşünmektedir. Bu durumun var olan eğitim sisteminin bu beceriyi sağlayamamasından, öğrencilerin sadece gördükleri konuya ve sınava odaklı çalışmalarından kaynakladığını belirten 
öğretmenler yalnızca ilgili derslerde akademik başarısı yüksek öğrencilerin kendi başına ilişki kurabildiklerini düşünmektedirler. Nitekim, alanyazına bakıldığında disiplinlerarası öğretim yaklaşımının öğretmenin derste yaptığı bilinçli ve sistematik ilişkilendirmelere dayalı olduğu görülmektedir (Brutlag ve Maples, 1992; Jacobs, 1989; Yalçın, 2013). Bu açıdan ele alındığında öğrencilerin öğretmen desteği olmadan bu ilişkilendirmeyi kendi başlarına yapmakta zorlanacakları görülmektedir.

Araştırmanın ikinci sorusu öğretmenlerin matematik dersini fen dersleriyle ilişkili bulup bulmadıkları ve eğer ilişkili olduğunu düşünüyorlarsa bu ilişkinin hangi konular arasında olduğunu saptamaya dönüktür. Araştırmaya katılan öğretmenler, matematiği sadece fen dersleriyle değil diğer tüm disiplinlerle bağlantılı olarak görmekte hatta tüm disiplinlerin temelinde evrensel bir alan olarak kabul etmektedirler. Matematiğin fen bilimleri ile yakın bağlantılı olduğunu düşünen öğretmenlerin yanıtlarında da somut örnekler vermeleri bu görüşlerini doğrular niteliktedir. Araştırmaya katılan öğretmenlerin fen bilimleri ile ilişkili gördüğü matematik konuları oran-orantı, türev trigonometri, olasılık, denklemler, integral ve üslü sayılarda yoğunlaşmaktadır. Çalışmaya katılan öğretmenler matematik konularından en çok oran-orantı konusunun tüm fen dersleriyle, türev konusun fizik dersiyle, logaritma konusunun kimya dersiyle, olasılık konusunun da biyoloji dersiyle ilişkili olduğunu düşünmektedirler. Daha ayrıntılı bir analiz yapıldığında matematik ve fizik dersleri arasında en çok türev-doğrusal hareket, integral-doğrusal hareket, birinci dereceden denklemler-1sı ve sicaklık, trigonometri-kuvvet, tork, denge arasında ilişki kurulmaktadır. Matematik ve kimya dersleri arasında ise en çok logaritma-asit-bazlar, oran orant1-mol kavram1, oran orant1-gazlar, oran orant1kimyasal denklemler, oran orantı kimyasal hesaplamalar konularının bağlantılı olarak kabul edildiği görülmektedir.

Ancak, ders uygulamalarına dönük üçüncü araştırma sorusunun sonuçlarına bakıldığında ilk iki sorudan farklı sonuçlarla karşılaşılmaktadır. Öğretmenler kavram hakkında olumlu tutuma ve bilgiye sahip olmalarına karşın, disiplinlerarası öğretimi derslerinde uygulayamadıklarını belirtmektedirler. Katılımcılardan bazıları zaman yetersizliği ya da programın yoğunluğu nedeniyle disiplinlerarası uygulamaları gerçekleştiremediklerini belirtmektedirler. Bu sonuç, Karakuş ve Aslan'ın (2016) araştırma sonuçlarıyla paralellik göstermektedir. $\mathrm{Bu}$ araştırmada da ilkokul öğretmenlerinin disiplinlerarası ilişkilendirmeye önem verdiklerini ancak zaman yetersizliği nedeniyle uygulayamadıklarını ortaya konulmuştur. Öte yandan, alanyazın incelendiğinde bir konunun öğretimi sırasında diğer derslerin ilgili konularıyla ilişkili örneklere de yer vermek zaman kaybına neden olmamakta; aksine derslerin daha anlaşılır olmasını ve verimli geçmesini sağlamaktadır (Jacobs ve Borland, 1986; Yıldırım, 1996). Bu açıdan ele alındığında öğretmenlerin zaman kaybı ile açıklamaya çalıştıkları durum, aslında disiplinlerarası öğretimin uygulanması konusundaki donanım eksikliklerinden kaynaklı olabilir.

Araştırmada öğretmenlerin disiplinlerarası öğretimle ilgili donanım eksikliklerinin olabileceğini destekleyen bir başka sonuç ise disiplinlerarası öğretim 
ile ilgili görüşlere dönük sorulara 70 katılımcının neredeyse tümünün yanıt vermesi ancak ders uygulamalarına dönük soru maddelerini yanıtlayanların sayısının giderek azalmasıdır (30 katılımcı). Örnek bir ders tasarımı ile ilgili soru ise 16 katılımcıyla sınırlı kalmıştır. Araştırmanın bu sonucu Coşkun'un (2013) araştırma sonuçlarıyla da paralellik göstermektedir. Coşkun'un gerçekleştirdiği araştırmanın sonuçlarına göre matematik öğretmenleri dersin öğretimi sırasında ilişkilendirmeye çok az yer vermektedir. Öğretmenler derslerdeki ilişkilendirmenin öğretmen tarafindan yapılması gerektiğini belirtmelerine karşın, ilişkilendirmeyi yapabilecek yeterliğe sahip değildirler.

Derslerinde disiplinlerarası uygulamaları gerçekleştirmediklerini belirten öğretmenlerin hizmet sürelerinin 2-6 yıl arasında olması; öte yandan örnek bir ders etkinliği hazırlayan öğretmenlerin hizmet sürelerinin 15 yıl ve üstü olması öğretmenlerin meslekte deneyim kazandıkça disiplinlerarası ders tasarlamada daha yeterli duruma gelmeleri ile açıklanabilir. Diğer bir deyişle meslekte hizmet süresi daha az olan öğretmenler, disiplinlerarası yaklaşımla ilgili olumlu görüşlere sahip olmakla birlikte disiplinlerarası yaklaşıma dayalı ders tasarımı yapmakta deneyimli öğretmenlere göre daha yetersiz kalmaktadırlar.

Mesleki deneyimleri daha az olan öğretmenlerin disiplinlerarası yaklaşıma dönük donanımlarının yeterli olmayışı öğretmenlerin hizmet öncesi eğitimlerinde disiplinlerarası öğretime ilişkin dersler alıp almadıkları ya da etkinlikler yapıp yapmadığ 1 sorusunu ortaya çıkarmaktadır. Nitekim, Aladağ ve Şahinkaya (2013) Sosyal Bilgiler ve Sınıf Öğretmenliği adaylarının sosyal bilgiler ve matematik derslerinin ilişkilendirilmesine yönelik yaptıkları çalışmalarında, öğretmen adaylarının ilişkilendirmenin yararlı olacağını düşündüklerini ancak bu ilişkilendirmenin nasıl yapılacağına ilişkin bilgi eksiklikleri olduğunu ortaya koymuşlardır. Ortaöğretim kurumlarına öğretmen yetiştiren programların disiplinlerarası anlayışa ne ölçüde katkı sağladığına dönük araştırmaların yapılması bu alandaki çalışmalara daha geniş bir çerçeve sağlayacaktır.

Araştırmada kimi katılımcılar disiplinlerarası öğretime uygun ders uygulamaları yapamamalarının bir nedeni olarak da ortaöğretim programlarındaki konu sıralamalarının uygun olmamasını göstermektedirler. Söz gelişi, fizik dersinde işlenecek bir ders için önkoşul niteliğinde olan bir konu, matematik dersinde bir sonraki dönemde yer alabilmekte ve öğrencilerin altyapısı yeni konuya geçmeye elverişli olmamaktadır. Ortaöğretim programlarının bütüncül bir bakış açısıyla yeniden gözden geçirilmesi ve birbirleriyle bağlantılı konuların belli bir sıralama içinde programlara yerleştirilmesi sağlanmalıdır. 2005 Matematik öğretim Programlarında (2017 programında yüzeysel olarak ifade edilse de) disiplinlerarası ilişkilendirmelerden söz edilmiş ancak bunun nasıl sağlanacağına ilişkin açıklama yapılmamıştır. Milli Eğitim Bakanlığı ve Eğitim Fakülteleri’nde görev yapan alan, program geliştirme ve ölçme değerlendirme uzmanlarının işbirliği ile birbirleriyle ilişkili konuların ve bu konularla ilgili örneklerin sunulduğu kılavuz kitaplar hazırlanarak öğretmenlerin kullanımına sunulabilir. Ayrıca matematik ve fen alanları 
ile program geliştirme anabilim dallarında görev yapan akademisyenler, ilgili alanın öğretmenleriyle ortak yürüteceği deneysel çalışmalarla ya da eylem araştırmalarıyla disiplinlerarası ders tasarımları hazırlayarak öğretmenlere kılavuz olacak araştırmaları alanyazına kazandırabilir. Söz gelişi, matematikteki türev konusunun anlatımı sırasında fizikteki doğrusal hareket konusundan örneklerin verildiği ders tasarımları hazırlanıp, deneysel desenli araştırmalarla bu öğretim tasarımlarının etkililiği incelenebilir.

Bu araştırmada ele alınan dersler temelde matematik olmak üzere, matematik ve fen dersleri ile sınırlıdır, ancak katılımcıların bazıları matematik ile sosyal bilimler dersleri arasında da ilişki bulunduğunu belirtmektedirler. Matematik ve sosyal bilimler ya da fen bilimleri ve sosyal bilimler dersleri arasındaki bağlantıları geliştirmeye dönük disiplinlerarası çalışmaların gerçekleştirilmesi, disiplinlerarası öğretimle ilgili daha geniş bir çerçeve oluşturmaya katkı sağlayacaktır.

Eğitim fakültelerinin yanı sıra ortaöğretim kurumlarına öğretmenler yetiştiren kaynaklardan birisi de Öğretmenlik Bilgisi (Pedagojik Formasyon) eğitimidir. Öğretmenlik Bilgisi eğitimine ilişkin uygulamalar üniversitelerden üniversitelere farklılık göstermektedir; Öğretmenlik Bilgisi eğitiminde ne düzeyde disiplinlerarası öğretime yer verildiği ya da ne tür uygulamalar yapıldığına ilişkin alanyazında henüz bir çalışmaya rastlanmamıştır. Ortaöğretim alan öğretmenliği programlarının yanı sıra Öğretmenlik Bilgisi programlarının da bu amaçla incelenmesi ve gerekirse düzenlemelere gidilmesi önerilmektedir.

Hizmet öncesi öğretmen eğitimi kadar önemli olan bir başka konu hizmet-içi eğitim çalışmalarıdır. Disiplinlerarası kavramı özellikle ilerlemeci felsefeye dayalı programların uygulanmasıyla beraber Türkiye'de de önem kazanmaya başlamıştır. Ancak disipliner öğretim anlayışı ile yetişmiş öğretmenlerin bu öğretim anlayışına uyum sağlamasında güçlükler yaşanabilir. Bu nedenle Milli Eğitim Bakanlığı'nın Eğitim Fakülteleri ile işbirliği içerisinde disiplinlerarası eğitime ilişkin hizmet-içi eğitimler sağlaması, öğretmenlerin ders içi uygulamalarını zenginleştirmeleri yolunda bir adım olabilir.

Son olarak, gelecekte yapılacak araştırmalarda öğretmenlerin mezun oldukları kurum ve hizmet süreleri de dikkate alınarak daha geniş bir katılımcı profilinin yer aldığı, daha büyük ölçekli araştırma projeleriyle Türkiye'nin disiplinlerarası öğretime ilişkin mevcut durumu ortaya konabilir. Ayrıca, Eğitim Fakülteleri’nde görev yapan alan uzmanları, program geliştirme ve ölçme değerlendirme uzmanlarının da konuyla ilgili görüşlerinin alınması yoluyla daha zengin verilere ulaşılması önerilmektedir.

\section{Kaynakça}

Aladağ, E. ve Şahinkaya, N. (2013). Sosyal bilgiler ve sınıf öğretmeni adaylarının sosyal bilgiler ve matematik derslerinin ilişkilendirilmesine yönelik görüşleri. Kastamonu Eğitim Dergisi, 21(1), 157-176. 
Aydın, G. ve Balım, A. G. (2005). Yapılandırmacı yaklaşıma göre modellendirilmiş disiplinlerarası uygulama: Enerji konularının öğretimi. Ankara Üniversitesi Eğitim Bilimleri Fakültesi Dergisi, 38(2), 145-166.

Bingölbali, E. ve Coşkun, M. (2016). İlişkilendirme becerisinin matematik öğretiminde kullanımının geliştirilmesi için kavramsal çerçeve önerisi. Eğitim ve Bilim, 4l(183), 233-249.

Bolat, M., Turna, Ö. ve Keskin, S. (2012, Haziran). Disiplinlerarası yaklaşım: Müzik, fizik, matematik örneği. Onuncu Ulusal Fen Bilimleri ve Matematik Eğitimi Kongresinde sunulan bildiri, Niğde Üniversitesi, Niğde.

Brutlag, D., and Maples, C., (1992). Making connections: Beyond the surface. The Mathematics Teacher, 85(3), 230-235.

Büyüköztürk Ş., Çakmak E. K., Akgün Ö. E., Karadeniz Ş. ve Demirel F. (2011). Bilimsel araştırma yöntemleri (8. Baskı). Ankara: Pegem Akademi.

Chrysostomou, S. (2004). Interdisciplinary approaches in the new curriculum in Greece: A focus on music education. Arts Education Policy Review, 105(5), 2329.

Coşkun, M. (2013). Matematik derslerinde iliş̧ilendirmeye ne ölçüde yer verilmektedir? Sinıf içi uygulamalardan örnekler (Yayımlanmamış yüksek lisans tezi). Gaziantep Üniversitesi Eğitim Bilimleri Enstitüsü, Gaziantep.

Gür, T. M. (2003). Araştırma ve eğitiminde disiplinlerarasılık. N. Babüroğlu (Ed). Eğitimin geleceği; üniversitelerin ve eğitimin değişen paradigması içinde (ss. 182-203). İstanbul: Sabancı Üniversitesi Yayınları.

Jacobs, H. H. (1989). The Growing Need for Interdisciplinary Curriculum Content. In H. H. Jacobs (Ed.) Interdisciplinary curriculum: Design and implementation. Alexandria: Assocation for Supervision and Curriculum Development.

Jacobs, H. H., and Borland, H. (1986) The interdisiplinary concept model: Theory and practice. Gifted Child Quartely, 30(4), 159-163.

Karakuş, M. ve Aslan, S. (2016). İlkokulda disiplinlerarası öğretime yönelik mevcut durumun incelenmesi. İlköğretim Online, 15(4), 1325-1344.

Michelsen, C. (2005). Expanding the domain, variables and functions in an interdisciplinary context between mathematics and pyhsics. In A. Beckmann, C. Michelsen and B. Sriraman (Eds.). Proceedings of the 1st international symposium of mathematics and its connections to the arts and sciences. (pp. 201214). Germany: Verlag Franzbecker.

Miles, M, B., and Huberman, A. M. (1994). Qualitative data analysis: An expanded Sourcebook. ( $2^{\text {nd }}$ Edition). Thousand Oaks, CA: Sage. 
Milli Eğitim Bakanlığı (2009). İlköğretim matematik dersi 6- 8. sinıflar öğretim programı ve kılavuzu. Ankara: MEB.

Milli Eğitim Bakanlığı (2013). Ortaöğretim matematik dersi ögretim programı ve kllavuzu. Ankara.

Milli Eğitim Bakanlığı (2017). Ortaöğretim matematik dersi ögretim programı ve kılavuzu. Ankara.

National Council of Teacher of Mathematics (2000). Principles and standards for school mathematics. Reston, VA: NCTM.

Özçelik, C. (2015). Disiplinlerarası ögretim yaklaşımına dayalı hazırlanan öğretim etkinliklerinin, ögrencilerin geometrik cisimlerin hacimleri konusundaki akademik başarllarına ve problem çözme becerilerine etkisi (Yayımlanmamış yüksek lisans tezi). Bartın Üniversitesi Eğitim Bilimleri Enstitüsü, Bartın.

Tchoshanov, M. A. (2011). Relationship between teacher knowledge of concepts and connections, teaching practice, and student achievement in middle grades mathematics. Educational Studies in Mathematics, 76(2), 141-164.

Turna, Ö ve Bolat, M. (2015). Eğitimde disiplinlerarası yaklaşımın kullanıldığ tezlerin analizi. Ondokuz Mayıs Üniversitesi Eğitim Fakültesi Dergisi, 34(1), 3555.

Yalçın, M. (2013). Biyoloji dersinde disiplinlerarası çalışmaların öğrenme üzerine etkilerinin incelenmesi. Ĕgitim ve Öğretim Araştırmaları Dergisi, 2(3), 117-122.

Yıldırım, A. (1996). Disiplinlerarası öğretim kavramı ve programlar açısından doğurduğu sonuçlar. Hacettepe Üniversitesi Ĕ̈itim Fakültesi Dergisi, 12, 8994.

Yıldırım, A. ve Şimşek, H. (2016). Sosyal bilimlerde nitel araştırma yöntemleri. Ankara: Seçkin Yayıncılık. 


\title{
Secondary School Teachers' Opinions and Course Practices on Interdisciplinary Teaching Approach ${ }^{1}$
}

\begin{tabular}{cccc}
\hline ARTICLE TYPE & Received Date & Accepted Date & Online First Date \\
Research Article & 07.23 .2018 & 04.08 .2019 & 04.09 .2019 \\
\hline
\end{tabular}

\section{Belgin Özaydınlı Tanrıverdi (iD ${ }^{2}$ and Cihan Kılıç}

\author{
Kocaeli University
}

\begin{abstract}
The purpose of this study is to demonstrate the views of secondary school mathematics, physics, chemistry and biology teachers on the basis of mathematics education and their classroom practices on the interdisciplinary teaching approach. Content analysis, of qualitative research methods, was used in the study. 70 teachers from various provinces in Turkey. The data collection tool consists of an open-ended questionnaire developed by the researchers. As a result of the study, it was found out that teachers have knowledge about interdisciplinary teaching at the conceptual level, and they think that interdisciplinary teaching was effective in developing students' academic success and positive attitudes. Teachers think that the most related topic in mathematics with all science subjects is rates-ratio, derivative is related to physics, logarithm is related to chemistry, and probability is related to biology. Despite these positive views on interdisciplinary teaching, most teachers are unable to perform interdisciplinary practices due to the lack of time / intensity in the curriculum. The fact that the teachers cannot organize an interdisciplinary lesson can be explained by their lack of knowledge and the difficulties in implementation despite the positive attitude they hold about interdisciplinary instruction.
\end{abstract}

Keywords: Interdisciplinary instruction, association skills, secondary education mathematics, physics, chemistry and biology teachers.

\footnotetext{
${ }^{1}$ This research has been presented as an oral paper at the International Curriculum and Instruction Congress (ICCI-EPOK, 2017) held in Muğla on October 25-28, 2017 and developed according to the recommendations.

${ }^{2}$ Corresponding Author: Assoc. Prof. Dr., Faculty of Education, Educational Sciences Department, Curriculum and Instruction. E-mail: belgintnvrd@ gmail.com, https://orcid.org/0000-0002-2134-8087

${ }^{3}$ Graduate student, Faculty of Education, Educational Sciences Department, Curriculum and Instruction. Email: cihankilic88@gmail.com, https://orcid.org/0000-0003-4618-8857
} 


\section{Purpose and Significance}

The concept of interdisciplinary education can be expressed as handling of a given central theme with its due relation or connection with other courses. The interdisciplinary approach is a more useful and alternative complement to the discipline-based education in terms of integration and problem-solving skills. It allows the individual to know himself, to be aware of what is happening around him and to create changes. This approach leads the individual to the need to listen to different views depending on the exchange of information and gives them the ability to look at his environment with the perspective of other disciplines. Since it has organic relation to many branches of science, mathematics is one of the leading sciences in view of interdisciplinary studies. National Council of Teacher of Mathematics (NCTM), which has been internationally recognized in the field of mathematics teaching and has been referenced since the 2005 mathematics curriculum by the Ministry of National Education, sees mathematical interconnection not only as a mere connection between mathematics' own concepts but also emphasizes the connection of its concepts with those of other sciences. Studies in recent years in Turkey reveals that both teachers and teacher candidates face a number of problems regarding the establishment of relations between math courses with other courses. Since the success of a curriculum is directly related to the quality of teachers and their in-class practices, it is obviously significant to focus on what teachers think, know and practice about the interdisciplinary understanding/teaching. This study aims at presenting the opinions and practices of the teachers who are interested in/concerned with interdisciplinary courses.

\section{Method}

Since this study aims at revealing the perspectives of teachers and their applications in their courses, a case study of qualitative research methods is used in order to analyze present situation and define the details, and to draw conclusions. The study group consists of 70 mathematics and science teachers. Considering that focusing on a single school type would be more effective, the study was conducted in a specific program with teachers having the same load of course hours and it consults to the opinions of the teachers of Mathematics and Science who work in Anatolian High Schools. 15 biology, 9 physics, 14 chemistry and 32 mathematics teachers participated in the study. The terms of office of the participants vary between 2-32 years.

The data collection tool consists of open-ended questions developed by researchers. In order to validate the data collection tool, 8 questions prepared on the basis of the related literature were presented to four teaching staff in the Department of Educational Sciences at Kocaeli University. One of the eight questions in the first phase was removed from the data collection tool after the pilot implementation with 10 teachers, because it could not be clearly understood by the participants due to the reasons caused by fuzziness or ambiguity in its nature. In order to ensure clarity and integrity in terms of the concept and also to prevent the misconceptions from reducing 
the reliability of the measurement tool, a text and visual material were added to the introduction of the data collection tool. Participants were asked about the reasons for their answers in order to be able to do more in-depth analysis of the questions. In order not to direct the participants to a specific response, both Why and Why not options were presented. Responses to all questions were asked to be given in writing by the participants in order to eliminate the time limit and to get their in depth-answers.

In the analysis of data, content analysis was used as one of qualitative data analysis methods. In this respect, data similar to each other are interpreted and arranged in a way that the reader can understand within the framework of certain concepts and themes. Analysis of data comprises four stages: 1) coding of the data, 2) finding the themes, 3) editing the codes and themes, 4) identifying and interpreting the findings. In the data analysis process, after the interviews were transformed or converted into written texts, codes and themes were created separately by two researchers and the codes that differed after the comparison were assigned to appropriate themes or canceled. In addition, data that are not related to research questions have been extracted and their entanglement in research data has been prevented. At the stage of preparing/sharing of the findings, some direct quotations of the teachers who participated in the interview were given.

\section{Results}

Considering the findings of the first question of the study, it can be said that the teachers who participated in the study had a conceptual level knowledge about the interdisciplinary teaching approach. Teachers participating in the study define the interdisciplinary teaching as a teaching of a given subject or course by relating it to another subject or course or teaching it in a holistic way or teaching it with its connection to other disciplines. Participants consider that the interdisciplinary education greatly improves students' academic success and attitude positively. The answers related to the academic achievement can be grouped in two categories: the training of the students who would think analytically, and the lessons which would be more effective/understandable. Learning will become much more permanent as it is holistic, multidimensional and therefore helpful in contributing to the education of individuals who will be analytical. In the second category, the efficiency and success of the courses will increase with the help of interdisciplinary teaching via more efficient and comprehensible courses, growing up students with a higher level of consciousness. When analyzed in terms of attitude, students will realize what they learn in the course can be used in life and thus they will break the negative prejudices about mathematics lesson.

When the findings of the second question of the study are examined in general, it is seen that participants consider mathematics lesson to be related to all courses including verbal courses or even see mathematics as a universal discipline at the center of all sciences. The lesson that mathematics teachers regard as the most related to mathematics is physics. Although chemistry and biology teachers state that mathematics is the basis of all sciences and related to their own courses, it is seen that 
physics teachers accept mathematics as the sine qua non of physics course. At this point, it can be stated that the answers of mathematics and science teachers are consistent with each other.

According to the participants, the most relevant mathematics subjects related to physics courses are ratio, derivative, trigonometry, integral and speed problems, while the mathematics subjects considered most related to chemistry are ratio, logarithm, exponential numbers and mixing problems. At this point the most striking point is that views of mathematics and chemistry teachers and those of mathematics and physics teachers are very close to one another, on their own fields of study. It is seen, on the other hand, that there is a great difference between the answers of mathematics and Biology teachers in terms of Biology lesson. While biology teachers considered the subject of genetics/inheritance in biology as related to mathematical probability, the same relation was not established by the mathematics teachers.

A large majority of the participants stated that the students had difficulty in associating the subjects without taking support from other sources. The reasons for this are explained by the fact that the existing education system cannot provide this skill, and that the students only focus on the subject they are studying and they act rather with exam oriented mentality. Teachers who respond positively to the question emphasize that only some successful students are able to establish relationship between disciplines.

Considering the findings of the third question of the study, it is seen that since it facilitated the teaching of the lessons and provided the participation of the students in the class, and since both the subject became better evident in the student's mind and became more comprehensible, and since permanent learning was provided, the teachers included interdisciplinary teaching in their lessons. Only 19 teachers answered the question related to their in-class practices. The majority of these responses are using examples related to one course during the instruction of a topic in another course; in other words giving examples of physics during instruction of a topic in mathematics.

\section{Discussion and Conclusions}

The first result obtained from this study is that teachers are conceptually informed about the subject; at the same time, they found that interdisciplinary teaching is effective in improving students' academic achievement and developing a positive attitude towards the course. However, almost all of the 70 respondents answered the first research question, while the number of respondents who answered the question items for the practice was gradually decreased (30 participants), and the question related to a sample lesson design was limited to 16 participants. This result reveals that teachers are conceptually informed about interdisciplinary teaching and that they do not have enough knowledge about how interdisciplinary teaching can be used effectively in improving students' academic achievement and developing positive 
attitude towards the course. In other words, teachers believe in the importance of interdisciplinary teaching but cannot apply it.

Although not stemming directly from the answers given to the questionaire of this study, another result is that teachers who have designed a sample course have a certain professional experience. In other words, although teachers with less service life have positive opinions about interdisciplinary education, they are less inadequate than experienced teachers in designing interdisciplinary courses. When the related literature is examined, it is seen that there is no sufficient study on the current state of interdisciplinary teaching in teacher education programs. The realization of descriptive studies in which teacher education programs are examined in terms of interdisciplinary teaching will shed light on program development studies in teacher education.

Teachers who participate in the study see mathematics in connection with all other disciplines and even accept it as a universal field at the basis of all disciplines. Teachers who think that mathematics is closely related to the sciences also give concrete examples in their responses to support their view. The academicians working in the departments of mathematics and science and program development departments can prepare the course designs in which that relation is established with experimental studies or via action researches to be conducted with the teachers of the related field, and provide the required literature to guide the teachers. As a matter of fact, in giving a lecture on the derivation in mathematics, examples of linear motion in physics can be given in a well prepared course design and the effectiveness of this interdisciplinary course design can be examined. 